\title{
ЗАРУБІЖНИЙ ДОСВІД НАДАННЯ ПУБЛІЧНИХ ПОСЛУГ У СФЕРІ ДЕРЖАВНОӤ РЕССТРАЦІї РЕЧОВИХ ПРАВ НА НЕРУХОМЕ МАЙНО
}

\author{
МАРТИНЮК Наталія Миколаївна - здобувач кафедри адміністративного \\ та митного права Університету митної справи та фінансів \\ https://orcid.org/0000-0001-7623-2260 \\ УДК: 342.95 \\ DOI 10.32782/LAW.UA.2020.3.27
}

\begin{abstract}
Наукова стаття присвячена висвітленню зарубіжного досвіду надання публічних послуг у сфері державної реєстрациї речових прав на нерухоме майно наступних краӥн: Болгарій, Білорусій, Росї, Польші, Чехї, Швейцарї, Італї, Іспанї, Німеччини, Франиї, США, Австралї тощо. У результаті вивчення світового досвіду зроблено висновок, що для ефбективного захисту прав на нерухомість як приватних власників, так $і$ держави необхідно створити єдину реєстрачійну систему, яка гарантуватиме надійність $і$ гласність ицвільного обороту нерухомості. Визначено иляхи імплементацї іноземного досвіду з метою удосконалення дiяльності суб'єктів публічної адміністрацї Украйни щодо надання публічних послуг у сфері державної реєстраиї речових прав на нерухоме майно.

Ключові слова: послуга, нерухоме майно, реєстр, державна реєстрачія речових прав на нерухоме майно.
\end{abstract}

Якісно новий правовий режим регулювання відносин між владними суб'єктами та громадянами - режим партнерських відносин - $є$ визначальною ознакою демократичної країни, що зумовило потребу у комплексному реформуванні управлінських процесів в державі, інститутів українського адміністративного права. Тому використання зарубіжного досвіду надання публічних послуг у сфері приводу державної реєстрації речових прав на нерухоме майно та впровадження його в законодавство України є безумовно актуальним на сьогоднішній час.
Нині, завдяки науковим працям: В.Б. Авер'янова, К.К. Афанасьєва Ю.П. Битяка, І.В. Дроздової, В.М. Гаращука, І.П. Голосніченка, С.О. Аегези, С.В. Ківалова, І.Б. Коліушка, А.Т. Комзюка, О.В. Кузьменко, Г.М. Писаренка, Я.О. Пономарьова, В.П. Тимощука та інших науковців, - досліджено ряд особливостей діяльності органів публічної влади з надання адміністративних послуг населенню. Зокрема, В. П. Тимощук, у посібнику «Адміністративна процедура та адміністративні послуги. Зарубіжний досвід і пропозиції для України» у главі третій детально розглянув адміністративну процедуру у зарубіжних країнах [1]. Aле у наукових дослідженнях питання вивчення зарубіжного досвіду з державної реєстрації речових прав на нерухоме майно майже не вивчались.

Метою даної статті є висвітлення зарубіжного досвіду правового регулювання надання публічних послуг у сфері державної реєстрації речових прав на нерухоме майно та його впровадження в Україні.

Для досягнення вищевказаної мети нами поставлені наступні завдання: проаналізувати світовий досвід забезпечення якості надання публічних послуг державної реєстрації речових прав на нерухоме майно; визначити шляхи імплементації іноземного досвіду в діяльність України. 


\section{Основний зміст роботи}

Об'єктами дослідження обрано 7 країн світу, а саме: Болгарія, Білорусь, Росія, Польща, Чехія, Швейцарія, Італія, Іспанія, Німеччина, Франція, США, Австралії, у яких протягом останнього десятиріччя проводились демократичні реформи. При цьому, одним із основних напрямів свого демократичного розвитку зазначені країни обрали саме підвищення якості надання послуг та зміцнення довіри до влади з боку населення, громадськості та приватного сектора.

У Болгарії надання публічних послуг реєстрацію актів з речових прав на нерухоме майно провадить нотаріус. Право власності на майно при цьому виникає з моменту внесення відповідного запису до державного реєстру. Так, нотаріус зобов' язаний здійснити реєстрацію незалежно від наявності заяви від зацікавленої особи. Нотаріус реєструє акти, на підставі яких виникають майнові правовідносини щодо об'єкта нерухомості. Запис про такі акти вчинюється у реєстрових книгах, які є підшивкою актів, що визначають правовий режим нерухомого майна. Відомості про здійснений запис носять відкритий характер і можуть надаватись зацікавленим особам як усно, так і письмово у формі відповідних довідок [2].

За реєстраційним законодавством Республіки Білорусь спеціально уповноваженим органом управління надання публічних послуг у галузі державної реєстрації нерухомого майна, прав на нього і операцій 3 ним є Комітет із земельних ресурсів, геодезії і картографії при Раді Міністрів Республіки Білорусь, а Науково-виробниче державне республіканське унітарне підприємство «Національне кадастрове агентство» цього Комітету $є$ республіканською організацією 3 ведення державної реєстрації нерухомого майна, прав на нього та правочинів 3 ним [3].

У російській системі реєстрації інформація також носить відкритий характер, проте вона не може бути надана в усній формі. Федеральний Закон «О государственной регистрации прав на недвижимое имущество и сделок с ним» встановлюе тільки письмову форму надання інформації у вигляді виписки 3 реєстру [4]. Слід було б врахувати до- свід надання інформації за зверненням особи, оскільки отримання такої інформації виконувало 6 функцію превентивного захисту свого майнового права.

Побудована система реєстрації прав на нерухоме майно в Російській Федерації необхідно доповнити не тільки реєстрацію виникнення, припинення, обтяження чи обмеження речових прав, але й деяких видів правочинів стосовно об'єктів нерухомості [5, c. 298].

У Республіці Польща реєстраційні провадження надання публічних послуг у справах реєстрації прав на нерухоме майно віднесено до компетенції місцевих судів. Покладання обов’язку провадити реєстраційні справи судами є запозиченням німецького досвіду. У Польщі також діє принцип: без реєстрації немає права. Більше того, ухилення або невчасне виконання обов'язку правонабувачем звернутись до суду 3 реєстрацією набутого речового права передбачає за польським законодавством про проступки (пол. wykroczenie) відповідальність у вигляді штрафу [6, с. 104]. Провадження у справах про притягнення осіб до відповідальності за цей вид протиправної поведінки здійснюється судами, вони ж виносять у цих справах рішення, застосовуючи до порушника накладення стягнення. Звертає на себе увагу цікаве правило в польському реєстраційному законодавстві: після укладення нотаріально засвідченого правочину, особливості якого полягають у тому, що нотаріус засвідчує не правочин, а підписи, які ставлять на ньому особи, він зобов'язаний у семиденний строк $з$ дня здійснення акту, що стосується нерухомості, відправити виписку 3 реєстрової нотаріальної книги до суду за місцем знаходження нерухомого майна для внесення судовим реєстратором запису в поземельну книгу [6, с. 105].

у Чехії надання публічних послуг щодо реєстрації нерухомості та пов'язаних з нею речових прав здійснюється місцевими органами кадастру, які входять до Чеського управління геодезії та картографії. Загальне правило виникнення речового права на нерухоме майно також присутнє у чеському реєстраційному та цивільному законодавстві. Реєстрація речових прав на нерухо- 


\section{Цивільне, підприсмницьке, господарське та трудове право}

мість здійснюється в кількох формах: шляхом внесення запису в реєстрову книгу або відмітки чи примітки, для кожної 3 яких законом передбачено спеціальний порядок здійснення. При цьому право власності та інші речові права на нерухоме майно реєструються тільки у формі внесення запису, накладення обмеження чи обтяження на речове право, а також їх зняття вноситься до реєстрової книги як примітка.

Згідно з чеським законодавством рішення реєстраційного органу про відмову здійснити державну реєстрацію речових прав можна оскаржити до вищестоящого органу - Чеського управління ведення кадастру. Таке право передбачене і українським реєстраційним законодавством, на відміну від російського, згідно з яким оскарження реєстраційних дій чи бездіяльності органів юстиції (відповідно до російського законодавства реєстрацію нерухомого майна та правочинів 3 ним покладено на органи юстиції) здійснюється виключно в судовому порядку.

Звернемо увагу на встановлення у Чехії відповідальності за правопорушення в галузі ведення кадастру. Законодавець передбачив відповідальність виключно у вигляді штрафів за порушення строків внесення інформації до кадастрових записів, неповідомлення заявнику інформації на запит щодо реєстрових записів на майно, за надання недостовірної інформації, яка стосується нерухомості.

Головним джерелом інформації про будь-яку нерухомість у Чехії 6 кадастр (Katastr nemovitosti') - комп'ютерна система, де зареєстровані всі земельні ділянки, будинки, квартири, нежилі приміщення (у тому числі й недобудовані), їхні геометричні розміри, площа й місцезнаходження. У кадастрі зазначено права власності й інші майнові права, зафіксовано особисті дані власників і співвласників. В управлінні кадастром будь-яка особа може одержати виписку з інформацією про об'єкт нерухомості, що їі цікавить, сплативши при цьому гербовий збір - 100 чеських крон [7].

У Швейцарії записом у реєстрі нерухомості презюмується дійсність правочину та служить (як і в Україні) вагомим доказом правового становища нерухомого об'єкта.
Такий запис презюмує наявність в особи прав та добросовісність цієї особи щодо набуття цих прав. Більше того у випадку включення запису в реєстр може бути захищено права і недобросовісного набувача. У реєстраційному законодавстві Швейцарії закріплений принцип публічної відкритості реєстру нерухомості. Проте на практиці отримати доступ до цієї інформації можна, лише обгрунтувавши свій інтерес. Проста цікавість не вважається «виправданою цікавістю».

В Італії поземельну книгу веде спеціально уповноважена особа - хранитель поземельної книги. Хранитель веде декілька книг для реєстрації окремих дій, наприклад книгу запису судових рішень, на підставі яких виникає речове право на нерухоме майно. Обов'язковій реєстрації в поземельній книзі підлягають договори про передачу прав власності на нерухоме майно, договори оренди нерухомого майна на строк більш як десять років та деякі інші договори, які набувають чинності стосовно третіх осіб після здійснення певного запису. Інформація, що міститься в поземельній книзі, є доступною для будь-якої особи. За запитом заявника хранитель поземельної книги зобов'язаний надати йому копію запису в поземельну книгу. Крім цього, сама поземельна книга може бути надана будь-якій заінтересованій особі.

Будь-яка нерухомість в Італії має бути зареєстрована в Консерваторії обліку нерухомості (Conservatoria dei Registri Immobiliari). 3 неї можна отримати інформацію про того, хто є власником нерухомості, яка іiі кадастрова вартість, точна площа, а також про наявність можливої заборгованості власника. Після підписання завершального акта купівлі-продажу нерухомість реєструється в Консерваторії обліку нерухомості впродовж двох місяців [8].

Для реєстрації будь-яких обмежень на власність, таких як іпотека, арешт чи будьякі інші обмеження в Італії створено спеціальний реєстр (Conservatoria dei registri), у якому зосереджено всю інформацію з приводу накладених уповноваженими органами обмежень права.

В Іспанії реєстраційна система введена в дію Законом про іпотеки 1861 року. Від- 
повідно до його вимог був створений Реєстр прав власності на нерухомість, у якому реєструються права власності на нерухоме майно, інші речові права, їх обмеження і обтяження. Він ведеться за реєстраційними округами, які не стикаються між собою і збігаються з кордонами адміністративних територій Іспанії. Реєстр ведеться в спеціальних книгах, які нумеруються і візуються суддею. Форма і порядок ведення цих книг визначаються Міністерством юстиції Іспанії. Реєстр ведуть особливі державні службовці - реєстратори, які в процесі своєї професійної діяльності підкоряються лише закону і повністю незалежні від держави, у тому числі і в питанні свого фінансування.

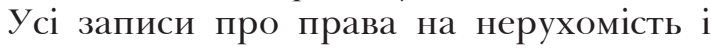
операції з нею реєструються в Реєстрі прав власності на нерухомість. Права на окремий об'єкт нерухомості реєструються на окремому аркуші запису в хронологічному порядку - таким чином фіксується процес переходу прав на нерухомість. Законним є лише останній правовласник, кожне право на нерухомість належить лише одному законному власникові. Усі незареєстровані права на нерухомість недійсні. На реєстратора покладена відповідальність за законність запису, у тому числі і за можливий збиток, заподіяний неправильним записом. Таким чином, тут також діє принцип: усе, що записано в реєстрі, є правильним і законним. Інформація Реєстру прав на нерухомість відносно прав, а також зареєстрованих обмежень і обтяжень на нерухоме майно відкрита для заінтересованих осіб.

Таким чином, в іспанській реєстраційній системі існує принцип повної гласності, тобто реєстрація права на нерухомість публічна і відкрита для ознайомлення [9, с. 62].

у сучасній об'єднаній Німеччині поземельна книга ведеться земельним судом за місцем знаходження об'єкта нерухомості.

При описі земельних ділянок та інших об'єктів нерухомості, розміщених на них, використовуються дані, надані кадастровою службою: межі ділянки, вид використання (забудована площа, вільна земля), місцезнаходження (адреса), розміри.

Реєстрація в поземельній книзі можлива на підставі заяви однієї із сторін правочину (у цьому випадку другу сторону представляе нотаріус) або спільної заяви. До заяви додається нотаріально посвідчений дозвіл на проведення реєстрації від особи, чиї права зачіпає реєстрація, а також додаткова заява від правовідчужувача i правоотримувача про передачу права власності. Окрім перерахованих документів, при передачі земельної ділянки необхідно надати оригінальну довідку фінансової служби, яка підтверджує сплату податку за придбання земельної ділянки і посвідчення територіальної громади про невикористання права переважного придбання.

Перелік документів, необхідних для надання публічних послуг щодо реєстрації речового права у Німеччині, досить короткий. Навіть договір купівлі-продажу особі, яка здійснює надання публічних послуг щодо реєстрації речового права на нерухоме майно, надавати не потрібно, оскільки за німецьким законодавством для передачі прав власності він не $є$ істотним. Це пояснюється тим, що при здійсненні правочину значну вагу має нотаріус.

Після перевірки документів уповноважена особа земельного суду проводить надання публічних послуг щодо реєстрації речових прав у поземельній книзі. Зауважимо, що кандидат на посаду реєстратора речових прав земельного суду у ФРН не обов'язково повинен мати юридичну освіту. Згідно 3 фактом реєстрації обом сторонам правочину надсилається повідомлення. У випадку якщо оплата за новопридбаний об'єкт нерухомості покупцем ще не здійснена, то можливий попередній запис про передачу права власності на користь покупця. Це гарантує його права на придбання об’єкта нерухомості [10, с. 107].

Французька система надання публічних послуг щодо реєстрації речового права не передбачає наявність поземельної книги як такої, тому що основною інформаційною ланкою в цій системі виступає не земельна ділянка, а правонабувач. Реєстрові книги, у яких ведуться реєстраційні записи про права на нерухомість, групуються на аркуші, що є відкритим для правовласника, вони отримали назву «Іпотечні книги». У Франції в кожному судовому окрузі знаходиться осо- 


\section{Цивільне, підприсмницьке, господарське та трудове право}

бливе бюро, що називається «Conservation des hypotheques» - («Сховище іпотек»), де здійснююються та централізуються усі формальності та дії, направлені на реєстрацію речового права [11, с. 104].

Нині в Европі відбуваються реформи національних реєстрових систем з метою приведення кадастрово-реєстраційних систем до єдиних стандартів, якими є, зокрема, такі: ведення системи реєстрації прав на нерухомість на основі записів про земельні ділянки (земельна ділянка та нерухоме майно розглядаються як єдиний об'єкт нерухомості); реєстрація прав на земельні ділянки та нерухоме майно здійснюється в одному реєстрі прав; реєстрація прав та ведення кадастрових карт здійснюється однією установою; реєстрація прав є адміністративною функцією (державна реєстрація прав повинна бути відокремленою від судових та (або) нотаріальних органів); послуги системи орієнтовані, насамперед, на користувача; система реєстрації прав повинна бути самоокупною [12].

Англо-американська система реєстрації правочинів щодо об'єктів нерухомості полягає у внесенні запису в реєстр за вільним вибором учасників правочину. Цю систему доцільніше було б назвати системою обліку документів, оскільки реєстрація є технічною операцією. Власником за англо-американськими правилами є останній добросовісний набувач нерухомого майна. Перехід права власності відбувається внаслідок укладання правочину та заволодіння об'єктом правонабувачем. У США покупцю необхідно відновити весь ланцюг попередніх документів на придбання нерухомості. Правочин може бути визнаний недійсним, якщо особи, що входять або не входять у ланцюг правочинів, можуть пред'явити права на об'єкт нерухомості. Недостатність законодавчих засобів компенсують адвокати та страхові компанії, які спеціалізуються на перевірці прав продавця. Наразі у Сполучених Штатах Америки активно розвивається система страхування ризиків втрати власності.

Погоджуючись 3 Я.О.Пономарьовою, яка у монографічному дослідженні «Адміністративні провадження 3 державної реєстрації речових прав на нерухоме майно» наголосила, що страхування повинно не за- мінювати реєстрацію прав, а служити інструментом захисту майнових прав. Зауважимо, що якою б доскональною не була система реєстрації, перехід права власності завжди буде операцією з різним ступенем ризику. Страхування титулу власника розвиватиметься і в Україні, але не замість системи реєстрації, а разом із цією системою реєстрації прав, створюючи додаткові гарантії прав добросовісних набувачів. [13, С. 134]

у 1858p. у Південній Австралії Р. Торренс ввів систему реєстрації прав на нерухоме майно, яка отримала його ім'я. Ця система поширилась по всій Австралії, іiї версії прийняті в Англії, в окремих штатах США та Канади, Новій Зеландії та в деяких африканських країнах. Ця реєстраційна система відноситься до систем реєстрації прав на земельні ділянки, згідно з якою держава гарантує точність титулу, який знаходиться в реєстрі, страхуючи від помилок, і за якою незареєстровані правочини не породжують правових відносин між суб'єктами, які не 6 учасниками правочину. Ця система близька до вітчизняної системи реєстрації прав: коли реєстрації підлягають права та обтяження. Перехід права власності при застосуванні системи Торренса здійснюється за заявою відчужувача [15].

Австралійська кадастрова система хоч i була створена під сильним впливом англійського загального законодавства, але основний акцент був перенесений на врахування потреб величезної країни, у якій почали інтенсивно розвиватись майнові відносини. Наслідком цього стала унікальна реєстраційна система [14].

Основною відмінністю цієї системи від європейських систем $є$ те, що система Торренса базується на кадастрових зйомках окремих земельних ділянок для індивідуальних власників 3 метою юридичної підтримки трансакцій нерухомого майна.

Отже, світовий досвід дає підстави вважати, що для ефективного захисту прав на нерухомість як приватних власників, так і держави необхідно створити єдину формальну реєстраційну систему надання публічних послуг. Вона гарантуватиме надійність і гласність надання публічних послуг щодо обороту нерухомості. 


\section{入ітература}

1. Тимощук В. П. Адміністративна процедура та адміністративні послуги. Зарубіжний досвід і пропозиції для України. К.: Факт, 2003. 496 с.

2. Недвижимость Болгарии: юридические аспекты покупки в собственность. Автор неизвестный [Електронний ресурс]. URL: http://www.bcprofi.ru/community/publications/ detail. php?ID=3855. - Назва з екрану.

3. О создании системы государственных организаций по государственной регистрации недвижимого имущества, прав на него и сделок с ним: Указ Президента Республики Беларусь от 10 декабря 2002 г. №603 [Електронний ресурc]. URL:: http://www. levonevski.net/pravo/razdel1/num4/1d4209. html.

4. О государственной регистрации прав на недвижимое имущество и сделок с ним: Федеральный Закон от 21 июля 1997 г.№ 122 Ф3 [Електронний ресурс]. URL: http:// www.garant.ru/law/ 11801341—000.htm.

5. Литвинов И. В. Государственная регистрация прав на недвижимое имущество и сделок с ним. Этапы развития и основные источники правового регулирования: справочник. Смоленск : Регистрационная палата Смоленской обл., 2004. 511 с.

6. Belniak S. Rozwój rynku nieruchomości w Polsce na tle krajów wysoko rozwiniętych. Kraków: Wydawnictwo Akademii Ekonomicznej w Krakowie, 2001. 204 s.

7. Нерухомість в Чехії [Електронний ресурс]. URL: http://interesting.in.ua/ neruxomist—v-chexi. - Назва з екрану.

8. Недвижимость в Италии [Електронний ресурc]. URL: http://www.eip.ru/main/ view4246.
9. Дмитриев А. В. Сравнительный анализ систем регистрации прав на недвижимость в России, Германии и Испании. Законодательство. 2000. № 11. С. $62-72$.

10. Кирсанов А. Р. Административноправовое регулирование регистрационной деятельности в сфере недвижимости: дис. ... канд. юрид. наук: спец. 12.00.14 «Административное право, финансовое право, теория управления». М., 2003. 223 с. [Электронный pecypc] URL: http://www.lawlibrary.ru/disser 2014673.html.

11. Никонов П. Н. Недвижимость, кадастр и мировые системы регистрации прав на недвижимое имущество. Аналитический обзор. СПб. : Роза мира, 2006. 180 с.

12. Юсип'юк I. Яким бути земельному кадастру України? Правовий тиждень. 44 (65). 30 жовт. 2007 р. [Електронний ресурc] URL: http://www.legalweekly.com.ua/ article/?uid $=114$.

13. Пономарьова Я.О. Адміністративні провадження з державної реєстрації речових прав на нерухоме майно : дис. ...кандидата юрид. наук : 12.00.07. Х., 2009. 204 c.

14. Дзюбенко О. А. Ідея верховенства права в контексті відомчого нормотворення [Електронний ресурс]. URL: www.library. ukma.kiev.ua/e-lib/NZ/NZV64_2007_law/16_ dzyubenko_ol.pdf.

15. Аегеза Є. О. Зарубіжний досвід надання публічних послуг та шляхи імплементації в вітчизняне законодавство України. Порівняльно-аналітичне право. 2016. № 1. С. 205-208 [Електронний ресурc]. URL: http://www.pap. in.ua/1_2016/61.pdf 